\title{
Conversion Efficiency of Fir Roundwood into Sawlogs
}

\author{
Markus Brandstetter, ${ }^{\mathrm{a}}$ Octavia Zeleniuc, ${ }^{\mathrm{a}}$ Gheorghe Pei, ${ }^{\mathrm{b}}$ and Mihaela Campean ${ }^{\mathrm{a}, *}$ \\ The objective of this research was to quantitate the amount of wood loss \\ that occurs during the processing of freshly harvested fir roundwood into \\ sawlogs. The influence of the felling damages and various growth defects, \\ e.g., curvature, taper, and forked growth, were taken into consideration. \\ The causes of wood loss and wood volume reduction during the three \\ primary operations of this processing chain, under the considered limited \\ conditions, were established. The greatest wood volume reduction \\ recorded was an $11 \%$ decrease, which was caused by the crosscutting of \\ the stems into shorter logs. Additional wood volume reductions were due \\ to the selection (grading) of the sawable logs and to debarking ( $7 \%$ and \\ $6 \%$, respectively). Some recommendations, in terms of industrial \\ applicability, i.e., methods to reduce the amount of wood loss, were also \\ formulated.
}

Keywords: Fir; Roundwood; Sawlogs; Wood losses; Crosscutting; Grading; Debarking; Conversion efficiency

Contact information: a: Transilvania University of Brasov, Faculty of Wood Engineering, Universitatii Str. Nr. 1, Brasov 500068 Romania; b: Transilvania University of Brasov, Faculty of Silviculture and Forest Engineering, Sirul Beethoven Str. Nr. 1, Brasov 500123 Romania;

*Corresponding author: campean@unitbv.ro

\section{INTRODUCTION}

The wood processing sector has made considerable progress in increasing the efficiency of wood utilization. According to the Food and Agriculture Organization of the United Nations (FAO), the global production of industrial roundwood in 2018 reached 2,028 million $\mathrm{m}^{3}$, which was processed into 493 million $\mathrm{m}^{3}$ of sawnwood, 408 million $\mathrm{m}^{3}$ of wood-based panels, 37 million $\mathrm{m}^{3}$ of pellets, and 838 million $\mathrm{m}^{3}$ of wood pulp and paper (including recovered paper) (FAO 2020a). This implies a wood utilization efficiency of $87.6 \%$.

In Romania, in 2018, the industrial roundwood production reached 10.436 million $\mathrm{m}^{3}$, out of which, 8.436 million $\mathrm{m}^{3}$ were converted into sawnwood, veneer, and parquet, and 1.09 million $\mathrm{m}^{3}$ was converted into wood-based panels (NSI Romania 2018). This equated to a wood utilization efficiency of $91 \%$, which is close to the value indicated at a global level by FAO.

In order to analyze the conversion efficiency of the total volume of felled wood processed into roundwood, and then further processed into sawnwood, pre-established conversion factors are needed as a quantification tool.

Conversion factors that cover the entire production process, i.e., the input of raw materials to the output of forest products, are a good indicator of efficiency levels and are often used as a benchmark for the overall effectiveness of a company at converting raw materials into finished or semi-finished products (FAO 2020b).

Different conversion factors can be calculated, depending on the ratio variables used. For example, Fig. 1 illustrates the conversion factor calculated as the ratio between 
the felled volume (in $\mathrm{m}^{3}$ ) and the resulted roundwood production $\left(\mathrm{RW}\right.$, in $\left.\mathrm{m}^{3}\right)$, which was based on data provided by UNECE and FAO (2005) for different European countries. With a conversion factor of 1.43 , Romania is situated above the average of 1.3.

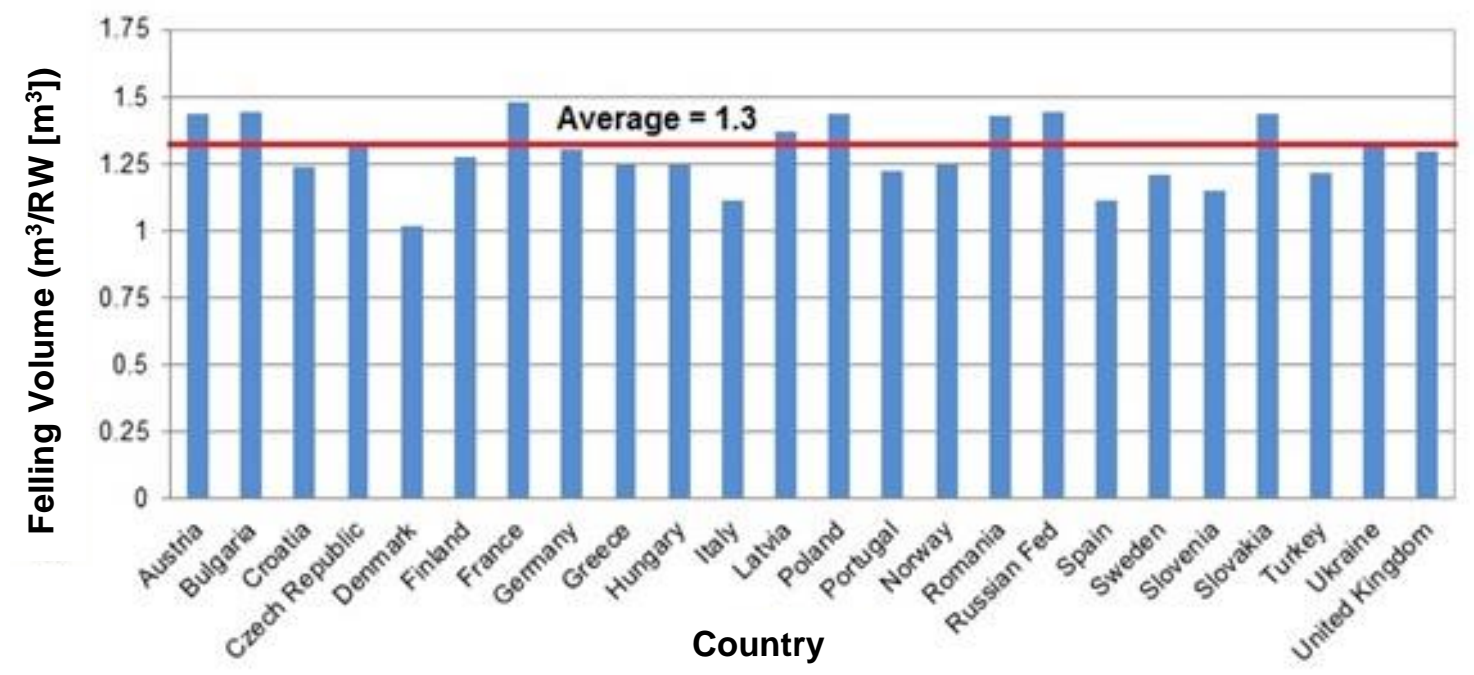

Fig. 1. Conversion factors for various European countries (graph made according to data provided by UNECE FAO 2005)

Other researchers have established different conversion factors: (1), the ratio of stacked wood to solid content, based on the ratio of the net wood stack volume to the gross wood stack volume, which is needed in the forest industry (Campu et al. 2015); (2), the ratio of board feet to cubic volume (Spelter and Alderman 2003); (3), the ratio of wood density at a $12 \%$ moisture content and the basic wood density, which has major implications in terms of the study of the role of forests in the global carbon cycle (Vieilledent et al. 2018); (4), the ratio of the delivered price per ton to a price per board foot or $\log$ s volume to weight, which is useful for field practitioners and landowners (Mercker and Taylor 2012); (5), the ratio of the volume of the wood raw material under bark $\left(\mathrm{m}^{3}\right)$ to the stack volume $\left(\mathrm{m}^{3}\right)$ for medium-sized pine and spruce, which are influenced by the diameter and log characteristics (mid-diameter, taper, ovality, and crook) (Heinzmann and Barbu 2017; Witkowska and Jodłowski 2018); and (6), the ratio of the volume of roundwood (input) to the volume of sawn timber (output), which establishes timber recovery efficiency (Ofoegbu et al. 2014). The conversion efficiency was also evaluated by different models, which help estimate the changes in efficiency from changing machinery or log characteristics, or management decisions that could influence the yield (Wade et al. 1992; Eguakun and Nwankwo 2016; Ojo et al. 2019).

In Romania, approximately 4 million $\mathrm{m}^{3}$ of coniferous roundwood is annually converted into sawnwood. Similar to other countries with large quantities of coniferous wood resources, it is important to maximize the utilization of this green resource, and to reduce the total wood waste as much as possible.

Multiple studies in the forestry sector have focused on maximizing the yield from processing the felled volume into roundwood, while studies in the sawmill sector have focused on maximizing the conversion efficiency of logs into sawnwood. However, little information is available on the segment in-between, namely the conversion of roundwood into sawlogs. There are many efficiency variables that affect the conversion factor when 
processing roundwood to sawlogs, i.e., the log quality and size, the methods of logging, and differences in how the roundwood volume is measured (FAO 2020a).

The main objective of the present study (performed under limited conditions) was to investigate the conversion efficiency of processing resinous (fir) roundwood into sawable logs. The influence of the initial dimensions (length and diameter), as well as the presence of shape deviations (curves and tapers) and other growth defects or felling damages were taken into consideration. These influences were considered in order to establish the primary causes which dictate the amplitude of the wood losses along the three primary operations that occur during the processing chain; the crosscutting of the roundwood into shorter logs, the selection (grading) of the sawable logs, and debarking of the logs. Based on the obtained results, recommendations envisaging optimization for the industrial practice were formulated.

\section{EXPERIMENTAL}

\section{Materials}

The wooden materials used within the experiments consisted of fir roundwood (Abies alba Mill.), harvested from the Romanian geographic region of Bicaz, Piatra Neamt County, as shown in Fig. 2. The growth characteristics of the plot are shown in Table 1.

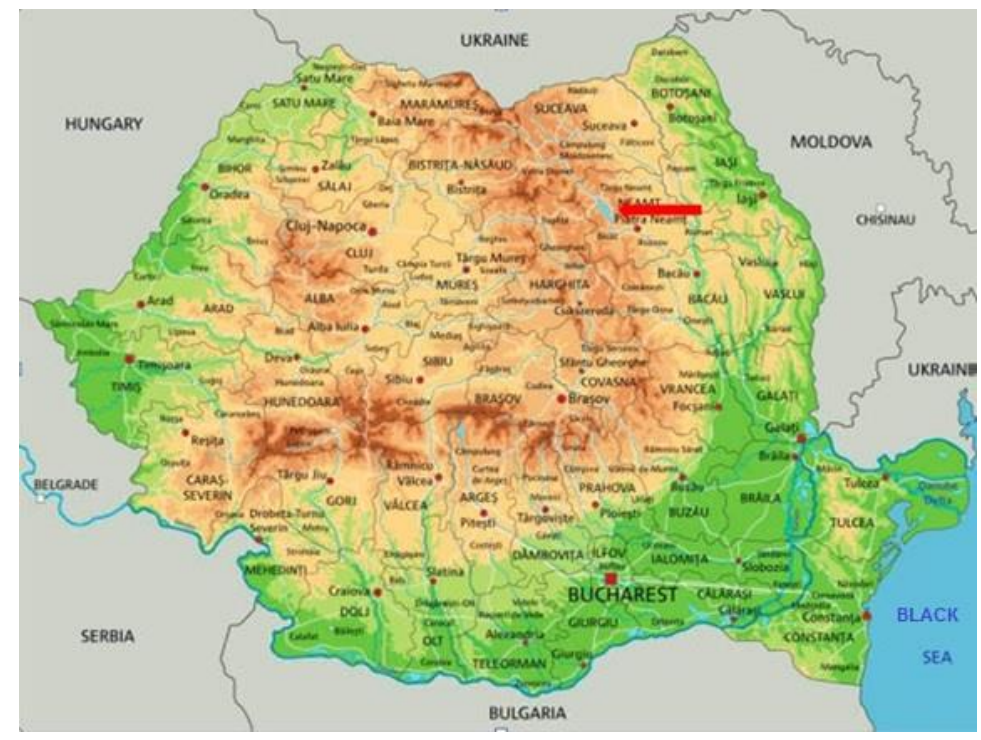

Fig. 2. Map of Romania, the red arrow shows the position of the region of Bicaz, Piatra Neamt County, in the Eastern Carpathians (https://harta-romaniei.org/harta-geografica-a-romaniei.html)

From this plot, eight harvest-eligible trees, which had a diameter of $25 \mathrm{~cm}$ to $35 \mathrm{~cm}$ at mid height, were chosen for this test.

After felling, the stems were pruned and numbered. Their dimensions (length, buttend diameter, top-end diameter, and mid-diameter at half of the length), were recorded using a caliper type 1208 (Silvanus Forstbedarf GmbH, Kirchdorf an der Krems, Austria) and a measuring tape (Bahco, SNA Europe SAS, Eragny-sur-Oise, France), both having a precision rating up to the nearest $\mathrm{cm}$. The diameters were measured in two perpendicular directions, then the arithmetic mean was calculated and rounded down. 
Table 1. Plot Characterization

\begin{tabular}{|c|c|}
\hline Geographic Region & $\begin{array}{c}\text { North-Eastern area of Romania, Eastern Carpathians, } \\
\text { Stanisoara Mountains }\end{array}$ \\
\hline Altitude & $\begin{array}{c}\text { The average altitude of the test surface was } 750 \mathrm{~m} \\
\text { Climate }\end{array}$ \\
$\begin{array}{c}\text { Mountain climatic zone of the Eastern Carpathians with a } \\
\text { moderate continental temperature } \\
\text { Average annual temperature: } 6.5^{\circ} \mathrm{C} \text { to } 7{ }^{\circ} \mathrm{C} \\
\text { Average annual rainfall: } 850 \mathrm{~mm}\end{array}$ \\
\hline Type of Soil & Brown soil \\
\hline $\begin{array}{c}\text { Type of Forest } \\
\text { Age of the Fir Trees from the } \\
\text { Test Surface }\end{array}$ & Mixed fir and beech forest \\
\hline
\end{tabular}

Being a cut-down for experimental purposes, where only selected trees were felled, the full harvesting process was made manually by means of a chainsaw Stihl Type MS 341 with $8 \mathrm{~mm}$ width of saw kerf.

The qualitative assessment of the stems after felling took into consideration any visible defects, e.g., the shape deviations, excessive proportion of knots, logging damages, etc., which were recorded for each stem on a characterization sheet.

The volume of each stem was calculated as function of the measured length and the diameter at mid length, as shown in Eq. 1,

$$
V_{\text {stem }}=\frac{\pi \cdot D_{m, s t e m}^{2} \cdot L_{\text {stem }}}{4} \quad\left(\mathrm{~m}^{3}\right)
$$

where $V_{\text {stem }}$ is the volume of the stem $\left(\mathrm{m}^{3}\right), L_{\text {stem }}$ is the length of the stem $(\mathrm{m})$, and $D_{m, s t e m}$ is the over-bark diameter at the mid length of the stem $(\mathrm{m})$.

The stems were cross-cut into shorter logs in order to obtain as many sawable logs as possible (Fig. 3). According to SR standard 1294:1993 (1993), sawable logs (in short, sawlogs) are considered logs with a diameter greater than $18 \mathrm{~cm}$, a minimum length of 250 $\mathrm{cm}$, and no visible defects (such as forked growths or soft-rot decays). However, when performant equipment is available for the conversion of the logs into lumber, logs with diameters as low as $10 \mathrm{~cm}$ are still allowed in the category of sawlogs (which was the case in the present research). The logs that after crosscutting did not fit in this category were classified either as industrial wood (which included thin logs with a diameters less than 10 $\mathrm{cm}$ and logs with major defects, such as severe shape deviations) or as firewood (which included all treetops, shortcuts, and wood with quality defects that are not allowed by the industrial wood group, e.g., soft-rot decays).

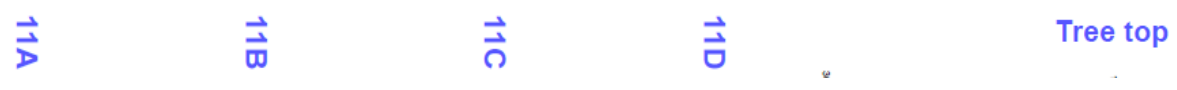

Fig. 3. A 3-D simulation of crosscutting stem $\mathrm{N}^{\circ} 11$ into four sawlog pieces (11A to 11D) and one piece of firewood (11E) 
The length and mid-diameter of each log that resulted from crosscutting the stems was measured using the same devices.

The volume of each log was calculated as function of the measured length and the diameter at mid length, as shown in Eq. 2,

$$
V_{\log }=\frac{\pi \cdot D_{m, \log \cdot L_{l o g}}^{2}}{4} \quad\left(\mathrm{~m}^{3}\right)
$$

where $V_{\log }$ is the volume of the $\log \left(\mathrm{m}^{3}\right), L_{\log }$ is the length of the $\log (\mathrm{m})$, and $D_{m, \log }$ is the over-bark diameter at the mid length of the $\log (\mathrm{m})$.

After measuring, the sawlogs were then separated and debarked.

The debarking was performed with a tandem ring debarker machine type A8-27 (Nicholson Manufacturing Ltd, Sidney, BC) (https://www.debarking.com/products/A8debarker.html). After debarking, all sawlogs were measured via a log shape scanner (Microtec, Brixen, Italy).

The log shape scanner functions on the principle of 3-D laser triangulation; infrared sources cover the shape of the log, and high resolution cameras provide the iRas XYposition data for the program. Utilizing this data, the scanner provides a true shape scanned image of the $\log$ (Fig. 4).

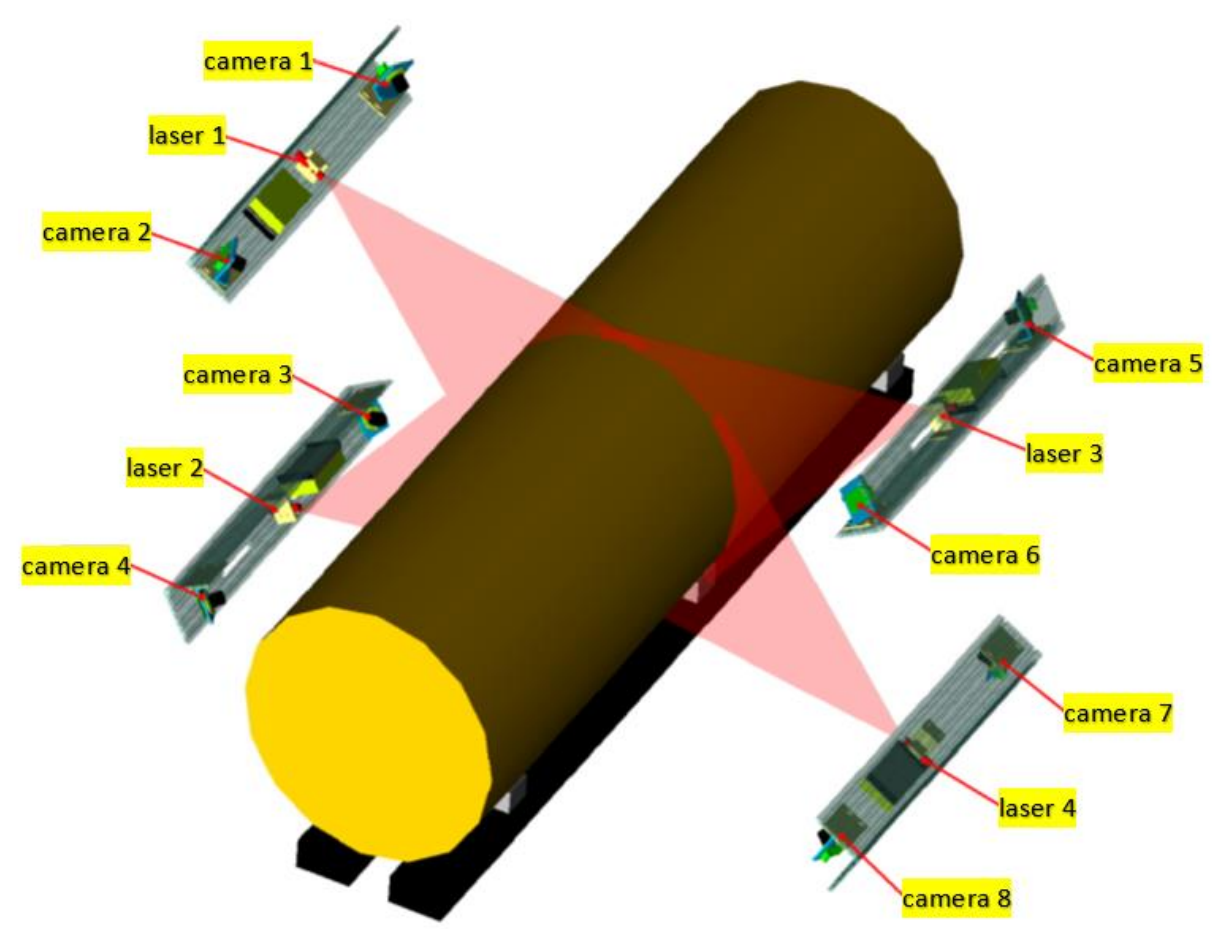

Fig. 4. Diagram of the setup of a DiShape scanner, operating via 3-D laser triangulation

Using the DiShape scanner, the dimensions (length, top-end diameter, middiameter, and butt-end diameter), shape deviations (curve and taper), and volume of each debarked sawlog were assessed.

The amount of wood loss was evaluated after each link of the processing chain: (1), the wood loss due to the crosscutting of the stem into logs was calculated as the difference between the stem volume $\left(V_{\text {stem }}\right)$ and the total volumes of all resulted logs (all, with bark $)\left(\sum V_{\text {all logs, with bark }}\right)$, according to Eq. 3 and Eq. 3', 


$$
\begin{aligned}
& W L_{\text {crosscutting }}=V_{\text {stem }}-\sum V_{\text {all logs, with bark }}\left(\mathrm{m}^{3}\right) \\
& W L_{\text {crosscutting }}=\sum \frac{\pi \times D_{m, \text { stem }}^{2} \times L_{\text {stem }}}{4}-\sum \frac{\pi \times D_{m, \log }^{2} \times L_{\text {log }}}{4} \quad\left(\mathrm{~m}^{3}\right)
\end{aligned}
$$

where $D_{m \text {, stem }}$ is the stem diameter $(\mathrm{m}), L_{s t e m}$ is the stem length $(\mathrm{m}), D_{m}$. log is the diameter of the $\log$ s resulted by crosscutting $(\mathrm{m})$, and $L_{\log }$ is the length of each $\log (\mathrm{m})$.

The wood loss due to the grading of the resulted logs, by taking into consideration only the volume of the sawable logs were calculated as the difference between the total volumes of all $\operatorname{logs}\left(\Sigma V_{\text {all logs, with bark }}\right)$ and the total volumes of the logs classified as sawlogs (all, with bark) $\left(\sum V_{\text {all sawlogs, with bark }}\right)$, according to Eq. 4 and Eq. 4',

$$
\begin{aligned}
& W L_{\text {grading }}=\sum V_{\text {all logs, with bark }}-\sum V_{\text {all sawlogs , with bark }} \quad\left(\mathrm{m}^{3}\right) \\
& W L_{\text {grading }}=\sum \frac{\pi \times D_{m, \log }^{2} \times L_{\log }}{4}-\sum \frac{\pi \times D_{m, \text { sawlog }}^{2} \times L_{\text {sawlog }}}{4} \quad\left(\mathrm{~m}^{3}\right)
\end{aligned}
$$

where $D_{m} \log$ is the diameter of the logs resulted by crosscutting $(\mathrm{m}), L_{\log }$ is the log length (m), $D_{m \text {. sawlog }}$ is the diameter of the logs graded as sawlogs (m), and $L_{\text {sawlog }}$ is the sawlog length $(\mathrm{m})$.

The wood loss due to the debarking of the sawlogs was calculated as the difference between the total volumes of the sawlogs with bark $\left(\sum V_{\text {all sawlogs, with bark }}\right)$, and the total volumes of the sawlogs without bark $\left(\Sigma V_{\text {all sawlogs, without bark }}\right)$, which was measured by the Microtec equipment, according to Eq. 5 and 5',

$$
\begin{gathered}
W L_{\text {debarking }}=\sum V_{\text {all sawlogs, with bark }}-\sum V_{\text {all sawlogs, without bark }} \quad\left(\mathrm{m}^{3}\right) \\
W L_{\text {debarking }}=\sum \frac{\pi \times D_{m, \text { sawlog with bark }}^{2} \times L_{\text {sawlog with bark }}}{4}-\sum V_{\text {sawlogs, without bark }}
\end{gathered}
$$

where $D_{m \text {. sawlog with bark }}$ and $L_{\text {sawlog with bark }}$ is the diameter $(\mathrm{m})$, and respectively length $(\mathrm{m})$ of each sawlog before debarking, and $D_{m}$. sawlog without bark and $L_{\text {sawlog without bark }}$ is the diameter $(\mathrm{m})$, and respectively length $(\mathrm{m})$ of the same sawlogs after debarking.

After each processing section, the wood yield was calculated, according to Eqs. 6, 7, and 8. Thus, the wood yield after crosscutting was calculated using Eq. 6,

$$
\eta_{\text {crosscutting }}=\frac{\sum V_{\text {all } \log s_{\text {, }} \text { with bark }}}{V_{\text {stem }}} \times 100 \%
$$

where $\Sigma V_{\text {all }}$ logs, with bark represents the total volumes of the logs with bark cut from a stem $\left(\mathrm{m}^{3}\right)$ and $V_{\text {stem }}$ is the volume of this stem $\left(\mathrm{m}^{3}\right)$.

Then, the wood yield after crosscutting and grading is shown in Eq. 7,

$$
\eta_{\text {crosscutting \& grading }}=\frac{\sum V_{\text {saw }} \log s_{\text {, with bark }}}{V_{\text {stem }}} \times 100 \%
$$

where $\Sigma V_{\text {sawlogs, with bark }}$ represents the total volumes of the sawlogs with bark cut from a stem $\left(\mathrm{m}^{3}\right)$ and $V_{\text {stem }}$ is the volume of this stem $\left(\mathrm{m}^{3}\right)$. with Eq. 8,

Finally, the wood yield after crosscutting, grading and debarking was calculated

$$
\eta_{\text {crosscutting \& grading \& debarking }}=\frac{\sum V_{\text {saw } \log s_{\text {, }} \text { without bark }}}{V_{\text {stem }}} \times 100 \%
$$


where $\Sigma V_{\text {sawlogs, without bark }}$ represents the total volumes of the sawlogs without bark, cut from a stem $\left(\mathrm{m}^{3}\right)$ and $V_{\text {stem }}$ is the volume of this stem $\left(\mathrm{m}^{3}\right)$.

The value calculated with Eq. 8 represented the conversion effciency of the selected stems into $\log$ s that were ready to be converted into lumber.

\section{RESULTS AND DISCUSSION}

The dimensions of the eight harvested stems, as well as the observations made insitu right after felling regarding the visible defects, are presented in Table 2. The number and type of logs obtained from each stem after crosscutting, as well as their over-bark volumes are presented in Table 3.

Table 2. Dimensions and Volume of the Harvested Fir Stems

\begin{tabular}{|c|c|c|c|c|c|c|c|}
\hline $\begin{array}{l}\text { Stem } \\
\mathrm{N}^{\circ}\end{array}$ & $\begin{array}{l}\text { Length } \\
\quad(\mathrm{m})\end{array}$ & $\begin{array}{l}\text { Butt-End } \\
\text { Diameter } \\
\text { (m) }\end{array}$ & $\begin{array}{c}\text { Mid- } \\
\text { Diameter } \\
(\mathrm{m})\end{array}$ & $\begin{array}{l}\text { Top-End } \\
\text { Diameter } \\
(\mathrm{m})\end{array}$ & $\begin{array}{l}\text { Taper } \\
(\mathrm{cm} / \mathrm{m})\end{array}$ & $\begin{array}{l}\text { Volume } \\
\qquad\left(\mathrm{m}^{3}\right)\end{array}$ & $\begin{array}{l}\text { Remarks Regarding } \\
\text { Visible Defects }\end{array}$ \\
\hline 2 & 30.37 & 0.45 & 0.25 & 0.05 & 1.3 & 1.490 & - \\
\hline 5 & 26.77 & 0.44 & 0.31 & 0.18 & 1.6 & 2.019 & $\begin{array}{l}\text { logging damage at } \\
0.2 \mathrm{~m} \text { and } 0.6 \mathrm{~m} \text { high }\end{array}$ \\
\hline 6 & 22.99 & 0.48 & 0.30 & 0.18 & 1.3 & 1.624 & $\begin{array}{c}\text { intergrown damage at } \\
6 \mathrm{~m} \text { height }\end{array}$ \\
\hline 8 & 27.08 & 0.54 & 0.32 & 0.10 & 1.6 & 2.177 & $\begin{array}{l}\text { logging damage at } \\
0.5 \mathrm{~m} \text { high }\end{array}$ \\
\hline 11 & 20.65 & 0.50 & 0.34 & 0.17 & 1.6 & 1.874 & curved \\
\hline 12 & 26.09 & 0.49 & 0.30 & 0.16 & 1.3 & 1.843 & $\begin{array}{l}\text { forked growth at } 6.5 \\
\text { m high }\end{array}$ \\
\hline 13 & 27.9 & 0.40 & 0.25 & 0.11 & 1.0 & 1.369 & eccentric growth \\
\hline 14 & 25.27 & 0.47 & 0.28 & 0.10 & 1.5 & 1.555 & - \\
\hline \multicolumn{6}{|c|}{ Total } & 13.952 & \\
\hline
\end{tabular}

Table 3. Volume, and Classification of the Post-Processing Fir Logs

\begin{tabular}{|c|c|c|c|}
\hline Stem $\mathrm{N}^{\circ}$ & $\begin{array}{l}\text { Number and Types of Fir Logs } \\
\text { Obtained By Crosscutting }\end{array}$ & $\begin{array}{l}\text { Volume (With Bark) } \\
\qquad\left(\mathrm{m}^{3}\right)\end{array}$ & $\begin{array}{l}\text { Total Volume (With } \\
\text { Bark) }\left(\mathrm{m}^{3}\right)\end{array}$ \\
\hline 2 & $\begin{array}{c}2 \mathrm{~A}-2 \mathrm{G}=\text { sawlogs } \\
2 \mathrm{H}=\text { industrial wood } \\
2 \mathrm{I}+\text { tree-top }=\text { firewood }\end{array}$ & $\begin{array}{l}1.218 \\
0.016 \\
0.016\end{array}$ & 1.249 \\
\hline 5 & $\begin{array}{c}5 A-5 G=\text { sawlogs } \\
5 H+\text { tree-top = firewood }\end{array}$ & $\begin{array}{l}1.750 \\
0.127\end{array}$ & 1.877 \\
\hline 6 & $\begin{array}{c}6 \mathrm{~A}-6 \mathrm{E}=\text { sawlogs } \\
6 \mathrm{~F}+\text { tree-top }=\text { firewood }\end{array}$ & $\begin{array}{l}1.285 \\
0.226\end{array}$ & 1.511 \\
\hline 8 & $\begin{array}{c}8 \mathrm{~B}-8 \mathrm{H}=\text { sawlogs } \\
8 \mathrm{~A}+8 \mathrm{I}+\text { tree-top }=\text { firewood }\end{array}$ & $\begin{array}{l}1.771 \\
0.077\end{array}$ & 1.848 \\
\hline 11 & $\begin{array}{l}11 \mathrm{~A}-11 \mathrm{D}=\text { sawlogs } \\
\text { tree-top = firewood }\end{array}$ & $\begin{array}{l}1.402 \\
0.179\end{array}$ & 1.581 \\
\hline 12 & $\begin{array}{c}12 \mathrm{~B}, 12 \mathrm{C}+12 \mathrm{E}-12 \mathrm{H}=\text { sawlogs } \\
12 \mathrm{~A}+12 \mathrm{D}+\text { tree-top }=\text { firewood }\end{array}$ & $\begin{array}{l}1.358 \\
0.141\end{array}$ & 1.499 \\
\hline 13 & $\begin{array}{c}13 B-13 H=\text { sawlogs } \\
13 A+13 I+\text { tree-top = firewood }\end{array}$ & $\begin{array}{l}1.219 \\
0.082\end{array}$ & 1.301 \\
\hline 14 & $\begin{array}{c}14 A-14 F=\text { sawlogs } \\
14 G+\text { tree-top = firewood }\end{array}$ & $\begin{array}{l}1.434 \\
0.072\end{array}$ & 1.506 \\
\hline \multicolumn{3}{|c|}{ TOTAL } & 12.372 \\
\hline
\end{tabular}


The total wood loss due to crosscutting, which was calculated according to Eq. 3 and Eq. 3', is presented in Table 4. The average value of this wood loss was $0.35 \mathrm{~m}^{3} \pm 0.12$ $\mathrm{m}^{3}$, which represented $11 \%$ of the initial volume. This was partly due to the fact that the harvesting was done manually, and so, a felling kerf was needed, which had to be cut off of every butt end of the stem, after felling. Thus, the part of the stem with the largest diameter was automatically lost. According to the obtained results, the average wood yield after crosscutting was $89 \%$.

Table 4. Wood Volume Loss Due to Crosscutting

\begin{tabular}{|c|c|c|c|c|}
\hline $\begin{array}{c}\text { Stem } \\
\mathrm{N}^{\circ}\end{array}$ & $\begin{array}{c}\text { Stem Volume } \\
\left(\mathrm{m}^{3}\right)\end{array}$ & $\begin{array}{l}\text { Total Volume of the } \\
\text { Resulted Logs }\left(\mathrm{m}^{3}\right)\end{array}$ & $\begin{array}{l}\text { Wood Loss } \\
\left(\mathrm{m}^{3}\right)\end{array}$ & $\begin{array}{c}\text { Percentage of Initial } \\
\text { Volume (\%) }\end{array}$ \\
\hline 2 & 1.490 & 1.249 & 0.241 & 16.18 \\
\hline 5 & 2.019 & 1.877 & 0.142 & 7.06 \\
\hline 6 & 1.624 & 1.511 & 0.113 & 6.97 \\
\hline 8 & 2.177 & 1.848 & 0.329 & 15.10 \\
\hline 11 & 1.874 & 1.581 & 0.293 & 15.63 \\
\hline 12 & 1.843 & 1.499 & 0.344 & 18.68 \\
\hline 13 & 1.369 & 1.301 & 0.068 & 4.96 \\
\hline 14 & 1.555 & 1.506 & 0.049 & 3.16 \\
\hline Total & 13.952 & 12.372 & 1.580 & - \\
\hline \multicolumn{3}{|c|}{ Average \pm Standard Deviation } & $0.35 \pm 0.12$ & 11.32 \\
\hline
\end{tabular}

Based on the values presented in Table 3, the total wood loss due to grading and the selection parameter of only sawable logs (by excluding the industrial wood and firewood parts) was calculated according to Eq. 4 and Eq. 4'. The results were presented in Table 5. According to the values obtained, the average loss in wood volume due only to grading was $0.12 \mathrm{~m}^{3} \pm 0.06 \mathrm{~m}^{3}$, which represented $7 \%$ of the initial wood volume and $7.5 \%$ of the total volume of all $\operatorname{logs}$ that were produced from each stem. This meant that a percentage of $92.5 \%\left(11.4 \mathrm{~m}^{3}\right)$ of the crosscut logs complied with the requirements of the best quality class, i.e., sawlogs, which was an exceptional result. Only $0.1 \%\left(0.016 \mathrm{~m}^{3}\right)$ were classified as industrial wood and $7.4 \%\left(0.92 \mathrm{~m}^{3}\right)$ were classified as firewood.

Table 5. Wood Volume Loss Due to Grading

\begin{tabular}{|c|c|c|c|c|}
\hline $\begin{array}{c}\text { Stem } \\
\mathrm{N}^{\circ}\end{array}$ & $\begin{array}{l}\text { Total Volume of } \\
\text { All Logs }\left(\mathrm{m}^{3}\right)\end{array}$ & $\begin{array}{l}\text { Total Volume of } \\
\text { the Sawlogs }\left(\mathrm{m}^{3}\right)\end{array}$ & Wood Loss $\left(\mathrm{m}^{3}\right)$ & $\begin{array}{l}\text { Percentage of } \\
\text { Total Volume of } \\
\text { All Logs (\%) }\end{array}$ \\
\hline 2 & 1.249 & 1.218 & 0.031 & 2.46 \\
\hline $5^{*}$ & 1.877 & 1.750 & 0.127 & 6.75 \\
\hline $6^{*}$ & 1.511 & 1.285 & 0.226 & 14.98 \\
\hline 8 & 1.848 & 1.771 & 0.077 & 4.18 \\
\hline $11^{*}$ & 1.581 & 1.402 & 0.179 & 11.32 \\
\hline $12^{*}$ & 1.499 & 1.358 & 0.141 & 9.39 \\
\hline 13 & 1.301 & 1.219 & 0.082 & 6.29 \\
\hline 14 & 1.249 & 1.434 & 0.072 & 4.80 \\
\hline Total & 12.372 & 11.437 & 0.935 & \\
\hline \multicolumn{3}{|c|}{ Average \pm Standard Deviation } & $0.12 \pm 0.06$ & 7.52 \\
\hline \multicolumn{5}{|c|}{$\begin{array}{l}\text { * The stems } N^{\circ} 5, N^{\circ} 6, N^{\circ} 11 \text {, and } N^{\circ} 12 \text { were marked in Table } 5 \text { in order to emphasize the } \\
\text { situations where the highest losses were recorded. These were clearly related to various } \\
\text { defects that could be observed during the quality assessment of the stems (as shown in Table } \\
\text { 2), i.e., harvesting damage (in the case of stems } N^{\circ} 5 \text { and } N^{\circ} 6 \text { ), or growth defects, such as a } \\
\text { heavily curved shape (in case of stem } N^{\circ} 11 \text { ) or forked growth (in case of stem } N^{\circ} 12 \text { ). }\end{array}$} \\
\hline
\end{tabular}


The average cumulated wood loss after crosscutting and grading was $2.515 \mathrm{~m}^{3}$, which represented $18 \%$ of the initial wood volume. According to the obtained results, the average wood yield after crosscutting and grading was $82 \%$. This value represented the percentual volume of sawlogs (with bark) that resulted from the processing of the selected stems.

Next, the amount of wood loss after debarking was evaluated according to Eq. 5 and Eq. 5'. The dimensions, volume, and shape deviations (taper and curvature) that were recorded via the Microtec scanner for each sawlog (after debarking) are presented in Table 6.

Table 6. Dimensions, Volume, and Shape Deviations of the Fir Logs Classified as Sawlogs (After Debarking)

\begin{tabular}{|c|c|c|c|c|c|c|c|}
\hline $\log N^{\circ}$ & $\begin{array}{l}\text { Length } \\
\text { (m) }\end{array}$ & $\begin{array}{c}\text { Top-End } \\
\text { Diameter } \\
\text { (Without } \\
\text { Bark) (m) }\end{array}$ & $\begin{array}{c}\text { Mid- } \\
\text { Diameter } \\
\text { (Without } \\
\text { Bark) (m) }\end{array}$ & $\begin{array}{l}\text { Butt-End } \\
\text { Diameter } \\
\text { (Without } \\
\text { Bark) (m) }\end{array}$ & $\begin{array}{c}\text { Taper } \\
(\mathrm{mm} / \mathrm{m})\end{array}$ & $\begin{array}{c}\text { Curvature } \\
(\mathrm{mm} / \mathrm{m})\end{array}$ & $\begin{array}{c}\text { Log } \\
\text { Volume } \\
\text { (Without } \\
\text { Bark) }\left(\mathrm{m}^{3}\right) \text { ) }\end{array}$ \\
\hline $2 \mathrm{~A}$ & 3.08 & 0.306 & 0.34 & 0.447 & 11 & 9 & 0.279 \\
\hline $2 B$ & 3.07 & 0.289 & 0.31 & 0.336 & 7 & 1 & 0.232 \\
\hline $2 \mathrm{C}$ & 3.06 & 0.267 & 0.28 & 0.298 & 8 & 1 & 0.188 \\
\hline $2 \mathrm{D}$ & 3.17 & 0.221 & 0.26 & 0.278 & 11 & 1 & 0.168 \\
\hline $2 \mathrm{E}$ & 3.10 & 0.203 & 0.23 & 0.244 & 12 & 2 & 0.129 \\
\hline $2 \mathrm{~F}$ & 3.09 & 0.169 & 0.19 & 0.213 & 12 & 1 & 0.088 \\
\hline $2 \mathrm{G}$ & 3.10 & 0.128 & 0.15 & 0.171 & 12 & 7 & 0.055 \\
\hline \multicolumn{7}{|c|}{ Total Sawlog Volume from Stem $\mathrm{N}^{\circ} 2$ : } & 1.139 \\
\hline $5 \mathrm{~A}$ & 3.13 & 0.364 & 0.38 & 0.437 & 11 & 1 & 0.355 \\
\hline $5 \mathrm{~B}$ & 3.08 & 0.351 & 0.36 & 0.375 & 6 & 1 & 0.313 \\
\hline $5 \mathrm{C}$ & 3.13 & 0.326 & 0.34 & 0.359 & 8 & 1 & 0.284 \\
\hline $5 \mathrm{D}$ & 3.09 & 0.297 & 0.31 & 0.336 & 7 & 1 & 0.233 \\
\hline $5 \mathrm{E}$ & 3.09 & 0.264 & 0.28 & 0.306 & 10 & 2 & 0.190 \\
\hline $5 \mathrm{~F}$ & 3.18 & 0.224 & 0.25 & 0.277 & 14 & 1 & 0.156 \\
\hline $5 G$ & 3.06 & 0.167 & 0.20 & 0.219 & 17 & 1 & 0.096 \\
\hline \multicolumn{7}{|c|}{ Total Sawlog Volume from Stem $N^{\circ} 5:$} & 1.628 \\
\hline $6 \mathrm{~A}$ & 3.11 & 0.346 & 0.37 & 0.479 & 13 & 6 & 0.334 \\
\hline $6 \mathrm{~B}$ & 3.19 & 0.326 & 0.34 & 0.361 & 8 & 3 & 0.289 \\
\hline $6 \mathrm{C}$ & 3.11 & 0.289 & 0.31 & 0.340 & 14 & 8 & 0.235 \\
\hline $6 \mathrm{D}$ & 3.09 & 0.259 & 0.28 & 0.299 & 11 & 1 & 0.190 \\
\hline $6 \mathrm{E}$ & 3.11 & 0.237 & 0.25 & 0.460 & 5 & 3 & 0.153 \\
\hline \multicolumn{7}{|c|}{ Total Sawlog Volume from Stem $N^{\circ}$ 6: } & 1.201 \\
\hline $8 \mathrm{~B}$ & 3.16 & 0.386 & 0.40 & 0.467 & 10 & 4 & 0.397 \\
\hline $8 \mathrm{C}$ & 3.10 & 0.365 & 0.37 & 0.398 & 5 & 2 & 0.333 \\
\hline $8 \mathrm{D}$ & 3.12 & 0.316 & 0.35 & 0.373 & 15 & 4 & 0.300 \\
\hline $8 \mathrm{E}$ & 3.09 & 0.288 & 0.30 & 0.329 & 2 & 4 & 0.218 \\
\hline $8 \mathrm{~F}$ & 3.10 & 0.242 & 0.26 & 0.285 & 14 & 4 & 0.165 \\
\hline $8 G$ & 3.08 & 0.192 & 0.22 & 0.248 & 13 & 1 & 0.117 \\
\hline $8 \mathrm{H}$ & 3.09 & 0.156 & 0.17 & 0.190 & 18 & 3 & 0.070 \\
\hline \multicolumn{7}{|c|}{ Total Sawlog Volume from Stem $N^{\circ} 8:$} & 1.600 \\
\hline $11 \mathrm{~A}$ & 3.16 & 0.348 & 0.40 & 0.535 & 19 & 5 & 0.397 \\
\hline $11 \mathrm{~B}$ & 3.13 & 0.349 & 0.37 & 0.389 & 8 & 3 & 0.336 \\
\hline $11 \mathrm{C}$ & 3.16 & 0.318 & 0.34 & 0.358 & 12 & 3 & 0.287 \\
\hline
\end{tabular}




\begin{tabular}{|c|c|c|c|c|c|c|c|}
\hline 11D & 3.15 & 0.270 & 0.31 & 0.341 & 15 & 3 & 0.238 \\
\hline \multicolumn{7}{|c|}{ Total Sawlog Volume from Stem $N^{\circ} 11$ : } & 1.258 \\
\hline $12 \mathrm{R}$ & 311 & 0339 & 037 & 0502 & 9 & 19 & 0334 \\
\hline $12 \mathrm{C}$ & 3.12 & 0.312 & 0.33 & 0.359 & 7 & 4 & 0.267 \\
\hline $12 \mathrm{E}$ & 3.11 & 0.275 & 0.30 & 0.331 & 10 & 1 & 0.220 \\
\hline $12 \mathrm{~F}$ & 3.16 & 0.247 & 0.27 & 0.296 & 9 & 6 & 0.181 \\
\hline $12 \mathrm{G}$ & 3.08 & 0.224 & 0.25 & 0.266 & 12 & 3 & 0.151 \\
\hline $12 \mathrm{H}$ & 2.93 & 0.179 & 0.20 & 0.229 & 16 & 3 & 0.092 \\
\hline \multicolumn{7}{|c|}{ Total Sawlog Volume from Stem $N^{\circ} 12:$} & 1.245 \\
\hline 13B & 3.21 & 0.298 & 0.31 & 0.370 & 5 & 6 & 0.242 \\
\hline $13 \mathrm{C}$ & 3.15 & 0.298 & 0.30 & 0.319 & 3 & 5 & 0.223 \\
\hline $13 \mathrm{D}$ & 3.13 & 0.262 & 0.29 & 0.308 & 6 & 1 & 0.207 \\
\hline $13 \mathrm{E}$ & 3.15 & 0.243 & 0.26 & 0.278 & 8 & 2 & 0.167 \\
\hline $13 \mathrm{~F}$ & 3.15 & 0.215 & 0.23 & 0.252 & 9 & 2 & 0.131 \\
\hline $13 G$ & 3.14 & 0.187 & 0.21 & 0.229 & 11 & 4 & 0.109 \\
\hline $13 \mathrm{H}$ & 3.13 & 0.138 & 0.16 & 0.186 & 13 & 3 & 0.063 \\
\hline \multicolumn{7}{|c|}{ Total Sawlog Volume from Stem $N^{\circ} 13:$} & 1.141 \\
\hline $14 \mathrm{~A}$ & 3.11 & 0.349 & 0.37 & 0.433 & 14 & 5 & 0.334 \\
\hline $14 \mathrm{~B}$ & 3.16 & 0.323 & 0.34 & 0.358 & 6 & 2 & 0.287 \\
\hline $14 \mathrm{C}$ & 3.14 & 0.297 & 0.32 & 0.337 & 4 & 2 & 0.252 \\
\hline 14D & 3.14 & 0.260 & 0.29 & 0.309 & 17 & 5 & 0.207 \\
\hline $14 \mathrm{E}$ & 3.13 & 0.229 & 0.25 & 0.274 & 6 & 3 & 0.154 \\
\hline $14 \mathrm{~F}$ & 2.98 & 0.169 & 0.20 & 0.224 & 17 & 5 & 0.094 \\
\hline \multicolumn{7}{|c|}{ Total Sawlog Volume from Stem $N^{\circ} 14:$} & 1.328 \\
\hline & & otal San & Jolume & out $\mathrm{Ba}$ & & & $10.538 \mathrm{~m}^{3}$ \\
\hline
\end{tabular}

The amount of wood loss after debarking was calculated for each sawlog, along with the total loss for all sawlogs that originated from the same stem (as shown in Table 7). According to the values obtained, the average loss due to debarking was $0.11 \mathrm{~m}^{3} \pm 0.03$ $\mathrm{m}^{3}$, which represented $6 \%$ of the initial wood volume and $8 \%$ of the volume of sawlogs with bark. These values are situated below the reference value of the debarking loss, which amounts at 11-12\% (FAO 2020b). This is mainly due to the performant debarking technique used.

Table 7. Total Wood Loss Due to the Debarking of the Sawlogs

\begin{tabular}{|c|c|c|c|c|c|c|c|c|c|c|}
\hline \multirow{2}{*}{$\begin{array}{c}\text { Log } \\
N^{\circ}\end{array}$} & $\mathrm{A}$ & $\mathrm{B}$ & $\mathrm{C}$ & $\mathrm{D}$ & $\mathrm{E}$ & $\mathrm{F}$ & $\mathrm{G}$ & $\mathrm{H}$ & \multirow{2}{*}{ Total } & $\begin{array}{c}\text { Percentage } \\
(\%)\end{array}$ \\
\hline 2 & 0.017 & 0.015 & 0.014 & 0.013 & 0.011 & 0.009 & - & - & 0.079 & 6.48 \\
\hline 5 & 0.019 & 0.018 & 0.034 & 0.015 & 0.014 & 0.013 & 0.010 & - & 0.123 & 7.03 \\
\hline 6 & 0.037 & 0.017 & 0.015 & 0.014 & - & - & - & - & 0.084 & 6.53 \\
\hline 8 & - & 0.041 & 0.037 & 0.017 & 0.030 & 0.026 & 0.011 & 0.008 & 0.171 & 9.65 \\
\hline 11 & 0.041 & 0.037 & 0.035 & 0.032 & - & - & - & - & 0.144 & 10.27 \\
\hline 12 & - & 0.037 & 0.016 & - & 0.015 & 0.014 & 0.012 & 0.019 & 0.114 & 8.39 \\
\hline 13 & - & 0.016 & 0.015 & 0.014 & 0.013 & 0.012 & 0.000 & 0.008 & 0.078 & 6.40 \\
\hline 14 & 0.037 & 0.017 & 0.000 & 0.030 & 0.013 & 0.010 & - & - & 0.106 & 7.39 \\
\hline \multicolumn{8}{|c|}{ Total } \\
\hline \multicolumn{18}{|c|}{ Average +/- Std. Dev. } & & & 0.785 & \\
\hline
\end{tabular}


According to the values obtained, the average cumulated wood loss after crosscutting, grading, and debarking amounted to $3.3 \mathrm{~m}^{3}$, which represented $24 \%$ of the initial wood volume. FAO (2020b) indicates a value of $34 \%$ for softwoods on this cumulated wood loss during the transformation of roundwood into sawlogs, but as already stated, this value greatly depends on the logging equipment used, the rules applied for sectioning the stem into shorter logs, and also on the debarking machine used.

Figure 5 illustrates the wood yield after performing all three operations in the technological chain. The average wood yield amounted to $76 \%$.

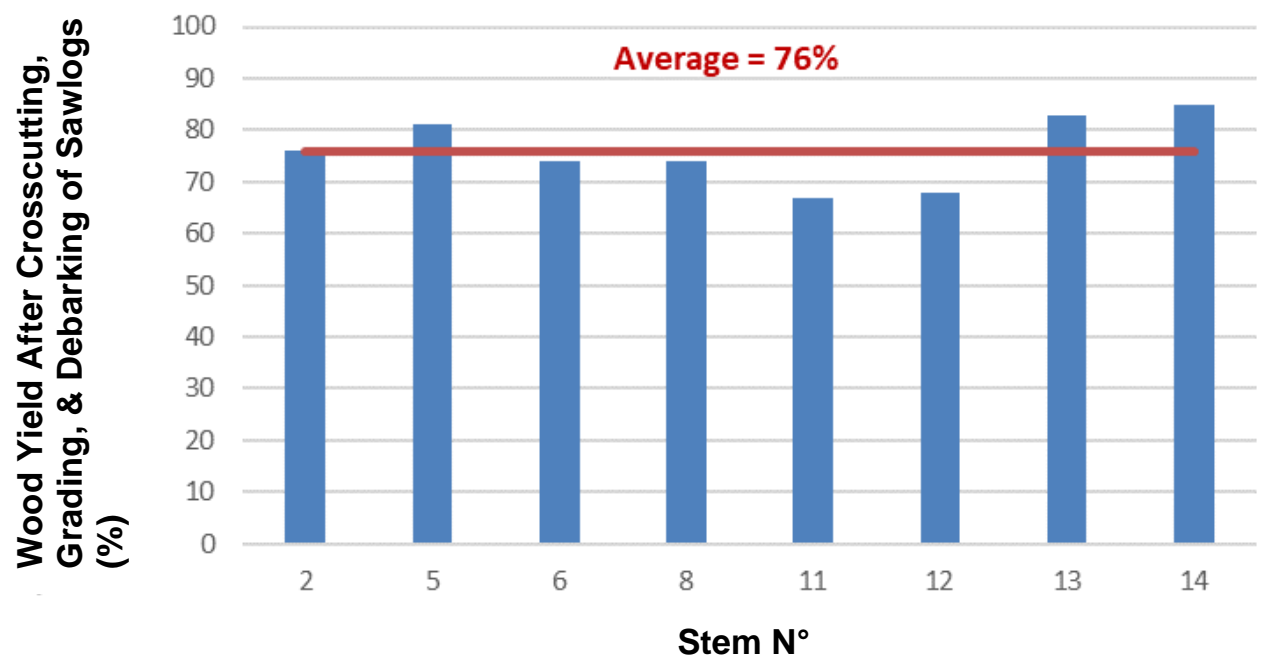

Fig. 5. The wood yield after crosscutting, grading, and debarking of sawlogs without bark

Figure 6 presents the evolution of the volume of each stem, from the initial stage through the three primary stages of the processing chain where wood loss occurred.

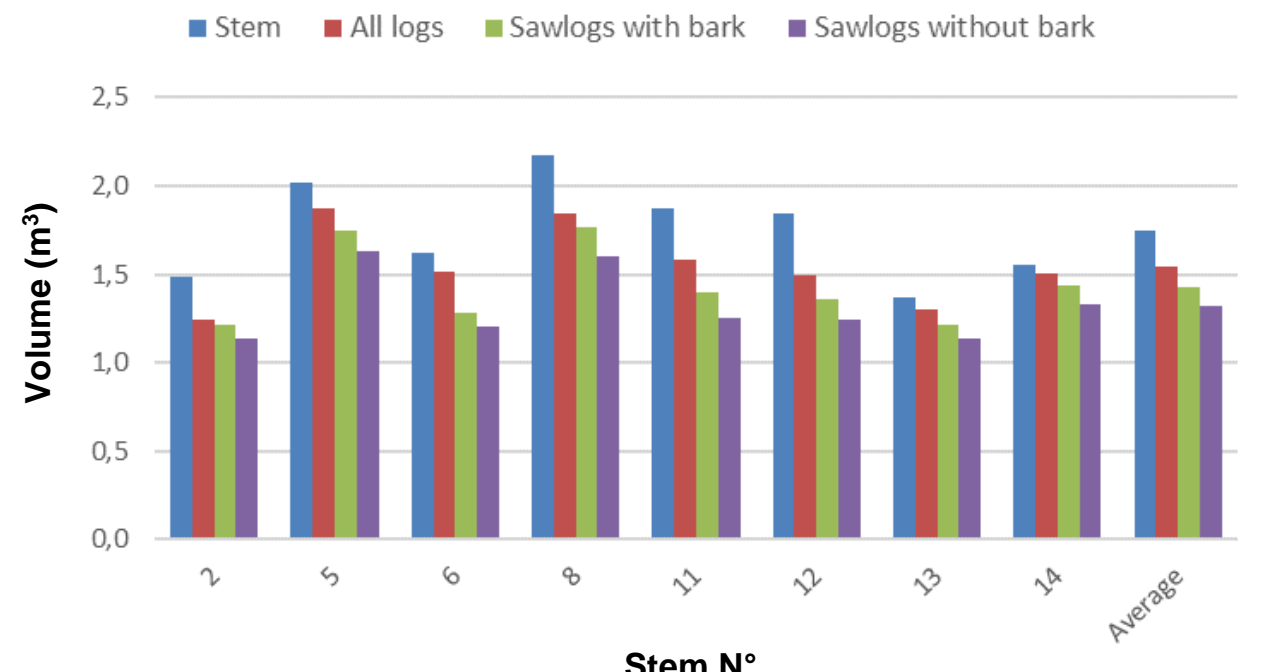

Fig. 6. Wood volume reduction during the processing chain of the stems into bark-free sawlogs (ready to be converted into lumber) 
The difference between the initial stem volume and the total volume of the debarked sawlogs (that resulted from the same stem), ranged between a minimum of $0.23 \mathrm{~m}^{3}$ (stems $\mathrm{N}^{0} 13$ and $\mathrm{N}^{\mathrm{o}} 14$ ) and a maximum of $0.62 \mathrm{~m}^{3}$ (stem $\mathrm{N}^{\mathrm{o}} 11$ ). The average value of this difference was $0.43 \mathrm{~m}^{3} \pm 0.16 \mathrm{~m}^{3}$.

\section{CONCLUSIONS}

1. During the processing chain converting roundwood into ready-to-saw logs, the greatest wood volume reduction occurred during the crosscutting of the stem into shorter logs, and its values ranged between a minimum of $3 \%$ and a maximum of $16 \%$, with an average of $11 \%$.

2. The wood volume reduction during the grading and the separation of industrial wood and firewood from sawable logs was slightly lower than the crosscutting values, ranging between a minimum of $2.5 \%$ and a maximum of $15 \%$, with an average of $7 \%$.

3. The wood volume loss during the debarking process was the lowest, with values ranging between a minimum of $4 \%$ and a maximum of $10 \%$, with an average of $6 \%$.

4. The conversion efficiency of processing fir roundwood into debarked sawlogs ranged between $67 \%$ and $85 \%$, with an average of $76 \%$.

5. The highest wood volume loss occurred during the crosscutting of the stem into shorter logs. This was partly due to the fact that the harvesting was done manually, and therefore a felling kerf was needed. As this part had to be cut off of every butt end of the stem, the part of the stem with the largest diameter was automatically lost. Optimization can be achieved only by the mechanization of the felling process, and also by utilizing a broader range of eligible lengths.

6. With a value of only $7 \%$, the wood volume loss due to the grading process can be considered acceptable when adhering to the current range of stem diameters.

7. As far as the wood volume loss due to the debarking process is concerned, it is very important to adjust the debarking pressure and the closing setpoints of the debarker in order to minimize wood volume losses.

\section{REFERENCES CITED}

Câmpu, V. R., Dumitrache, R., Borz, S. R., and Timofte, A. L. (2015). "The impact of log length on the conversion factor of stacked wood to solid content," Wood Research 60(3), 503-518.

Eguakun, F. S., and Nwankwo, P. (2016). "Predicting wood conversion efficiency in Illoabuchi sawmill, Port Harcourt, Nigeria," New York Science Journal 9(11), 20-26. DOI: 10.7537/marsnys091116.04

Food and Agriculture Organization of the United Nations (FAO) (2020a). "Forest products statistics. Facts and figures," (http://www.fao.org/forestry/statistics/80938/en/), Accessed 31 March 2020

Food and Agriculture Organization of the United Nations (FAO) (2020b). "Forest 
product conversion factors," (http://www.fao.org/3/ca7952en/CA7952EN.pdf), Accessed 23 May 2020

Food and Agriculture Organization of the United Nations (FAO) (2018). "The state of the world's forests 2018 - Forest pathways to sustainable development," (http://www.fao.org/3/i9535en/i9535en.pdf), Accessed 25 Feb 2020.

Heinzmann, B., and Barbu, M.-C. (2017). "Effect of mid-diameter and log parameters on the conversion factor of cubic measure to solid measure concerning industrial timber," ProLigno 13(1), 39-44.

Mercker, D., and Taylor, A. (2012). Estimating Weight of Logs and Standing Timber: A Guide for Foresters, the Forest Industry and Landowners (Report No. SP 748), University of Tennessee, Institute of Agriculture, Knoxville.

Nicholson Manufacturing (2010). Nicholson A8: High speed fixed ring debarker (https://www.debarking.com/products/A8-debarker.html). Accessed 14 May 2020

Ofoegbu, C., Ogbonnaya, S., and Babalola, F. D. (2014). "Sawmill conversion efficiency and wood recovery of timber species in cross river state Nigeria," Agriculture and Forestry 60(1), 105-113. DOI: 10.17707/AgricultForest

Ojo, A. R., Olayiwola, Y. B., and Owoloja, A. O. (2019). "Influence of log form on conversion efficiency of some sawmills in Oluyole local government of Oyo state, Nigeria," International Journal of Agriculture and Plant Science 1(4), 14-18.

Romanian National Institute of Statistics (NSI Romania) (2018). "Volume of wood harvested in Romania," (in Romanian) (http://www.insse.ro/cms/sites/default/ files/field/publicatii/volumul_de_lemn_exploatat_in_anul_2018.pdf), Accessed 26 Feb 2020.

Spelter, H., and Alderman, M. (2003). Profile 2003: Softwood Sawmills in the United States and Canada (Report No. FPL-RP-608) USDA Forest Service, Forest Products Laboratory, Madison, WI.

SR 1294:1993 (1993). "Resinous roundwood for industry,” (in Romanian language). Romanian Standardization Association, Bucuresti, Romania

United Nations Economic Commission for Europe (UNECE) and Food and Agriculture Organization of the United Nations (FAO) (2005). "Forest product conversion factors: Project overview and status," (https://www.unece.org/fileadmin/DAM/timber/meetings/forest-products-conversionfactors.pdf), Accessed 29 Feb 2020.

Vieilledent, G., Fischer, F. J., Chave, J., Guibal, D., Langbour, P., and Gerard, J. (2018). "New formula and conversion factor to compute basic wood density of tree species using a global wood technology database," American Journal of Botany 105(10), 1653-1661. DOI: 10.1002/ajb2.1175

Wade, M. W., Bullard, S. H., Steele, P. H., and Araman, P. A. (1992). "Estimating hardwood sawmill conversion efficiency based on sawing machine and log characteristics," Forest Products Journal 42 (11-12), 21-26.

Witkowska, J., and Jodłowski, K. (2018). "Determining the conversion factors for selected lengths of medium-sized pine and spruce wood in the S2 group," Forest Research Papers 79(1), 69-76. DOI: 10.2478/frp-2018-0008.

Article submitted: March 20, 2020; Peer review completed: May 3 2020; Revised version received and accepted: May 29, 2020; Published: June 2, 2020.

DOI: $10.15376 /$ biores. 15.3.5653-5665 